\title{
The Effect Of Return On Equity, Price Earning Ratio And Debt To Equity Ratio On Return Of Shares Of Food And Beverages Companies Registered In Indonesia Stock Exchange For 2012-2014
}

\author{
Izzakud Wahasanah and Sengguruh Nilowardono \\ Program Studi Manajemen, Fakultas Ekonomi Dan Bisnis \\ Universitas Narotama Surabaya \\ Email Author: sengguruh@narotama.ac.id
}

\begin{abstract}
The presence of the capital market in Indonesia is marked by the number of investors who have started investing in the food and beverage industry. The more rapid development of the food and beverage sector is followed by the increasing demand for public needs, thus making investors need funds from external sources. Funds from external sources can be obtained through the capital market. Therefore, the owner is directed to the capital market which can attract investors. Investors tend to choose stocks that can provide maximum returns. This study aims to determine the effect of return on equity (ROE), price earning ratio (PER), and debt to equity ratio (DER) on stock returns in food and beverage companies listed on the IDX (case study 2012-2014). The analysis technique used in this research is multiple linear regression to obtain a comprehensive picture of the relationship between one variable and another. The explanatory technique used is the multiple linear regression method ( $\mathrm{F}$ test and $\mathrm{T}$-test) coefficient of determination analysis and correlation coefficient analysis. So it can be concluded that the variable (X) is ROE, PER, and DER and variable (Y) RETURN SHARES. The results of the study show that together the financial performance as measured by ROE, PER, and DER has a significant effect on stock returns in food and beverage companies in the 2012-2014 period. The results of this study are expected that the variables ROE, PER, and DER can be used as a good guideline for the management of the company in improving financial performance, especially capital management, debt, and the ability to generate profits, or by investors in determining investment strategies.
\end{abstract}

Keyword:

ROE,PER,DER, Stock Return

\section{Pendahuluan}

Pasar modal adalah perlengkapan sektor keuangan terhadap dua lembaga lain yaitu bank dan lembaga pembiayaan yang memberikan jasa untuk menghubungkan dana dari pihak yang memiliki kelebihan dana (investor) kepada pihak sektor produktif yang membutuhkan dana.

Return saham adalah hasil sebuah investasi yang dilakukan oleh investor yang menanam modal nya pada instrumen saham. Return tersebut dapat berupa capital gain dan deviden dari investasi pada saham dan pendapatan bunga dari investasi pada surat hutang. Return tersebut menjadi indikator untuk meningkatkan kemakmuran para investor ( Suharli, 2004 ).

Return saham sangat berkaitan dengan harga saham, kerena untuk menghitungnya digunakan harga saham penutupan dan harga saham awal. Harga saham suatu perusahaan mengalami fluktuasi setiap waktu, bahkan suatu saham bisa mengalami perubahan harga dalam hitungan menit. Fluktuasi harga saham tersebut disebabkan oleh banyak faktor, salah satunya adalah jumlah permintaan dan penawaran dari saham. Jika suatu saham banyak dijual investor, maka biasanya akan menyebabkan harga saham mengalami penurunan.

Harga saham adalah nilai suatu saham yang mencerminkan kekayaan perusahaan yang mengeluarkan saham tersebut, dimana perubahan atau fluktuasinya sangat dintentukan oleh kekuatan penawaran dan permintaan yang terjadi di bursa (pasar sekunder). Semakin banyakn investor yang membeli atau menyimpan saham maka harga saham semakin naik, sebaliknya semakin banyak investor yang ingin menjual atau melepaskan suatu saham, harga akan bergerak turun ( Koetin, 1992 ).

Analisis fundamental, investor dapat melakukan analisis berdasarkan kinerja perusahaan. Analisis ini terutama menyangkut faktor-faktor yang memberi informasi tentang kinerja perusahaan, seperti kemampuan 
manajemen dalam mengelola kegiatan operasional perusahaan, prospek bisnis perusahaan dimasa mendatang dan sebagainya.

Sedangkan analisis teknikal adalah menganalisis harga saham berdasarkan informasi yang mencerminkan kondisi perdagangan saham, keadaan pasar, permintaan dan penawaran harga dipasar saham, flutuasi kurs, volume transaksi dimasa lalu. Analisis teknikal menegaskan bahwa perubahan harga saham terjadi bedasarkan pola terilaku harga saham itu sendiri, sehingga cenderung untuk terulang kembali. Asumsi dasar dari analisis teknikal adalah bahwa jual beli saham merupakan berspekulasi ( Husnan, 2003 ).

Salah satu analisis yang digunakan untuk menganalisis kinerja keuangan dengan melakukan analisis rasio keuangan. Analisis rasio keuangan merupakan alat yang digunakan untuk membantu menganalisis laporan keuangan perusahaan sehinga dapat diketahui kekuatan dan kelemahan suatu perusahaan. Analisis rasio juga menyediakan indikator yang dapat mengukur tingkat profitabilitas, liquiditas, pendapatan, pemanfaatan asset dan kewajiban perusahaan ( Munawir, 2004 ).

Dipilihnya perusahaan food and beverages sebagai objek penelitian ini merupakan salah satu bentuk perusahaan yang cukup berkembang pesat saat ini ( Sulistyo, 2006 ). Dari penguji-pemguji yang telah dilakukan oleh penelitian terdahulu terjadi perbedaan hasil penelitian mengenai kinerja keuangan perusahaan yang berpengaruh terhadap return saham. Berdasarkan uraian latar belakang diatas penelitian ini ingin mengetahui apakah penelitian ini berpengaruh secara simultan atau parsial terhadap return saham maka penelitian ini mengambil judul “ pengaruh return on equity, price earning ratio dan debt to equity ratio terhadap return saham perusahaan food and beverages yang terdaftar di bursa efek indonesia periode 2012-2014.

Dalam penelitian ini diajukan hipotesis.Hipotesis adalah jawaban sementara terhadap masalah penelitian yang disajikan dalam bentuk pertanyaan. Berdasarkan perumusan masalah, landasan teori, dan rerangka konseptual diuraikan hipotesis penelitian yang diajukan dalam penelitian ini adalah sebagai berikut :

1. Return on Equity (ROE) berpengaruh secara signifikan terhadap Return Saham perusahaan food and beverages yang terdaftar di bursa efek imdonesia periode 2012 - 2014.

2. Price Earning Ratio (PER) berpengaruh secara signifikan terhadap Return Saham perusahaan food and beverages yang terdaftar di bursa efek imdonesia periode 2012 - 2014.

3. Diduga debt to Equity Ratio (DER) berpengaruh secara signifikan terhadap Return Saham perusahaan food and beverages yang terdaftar di bursa efek imdonesia periode 2012 - 2014.

4. ROE, PER dan DER secara simultan berpengaruh secara signifikan terhadap return saham pada perusahaan food and beverages periode 2012-2014.

\section{Metode Penelitian}

Metode dan pendekatan penelitian ini adalah asosiatif. Penelitian asosiatif merupakan penelitian yang bertujuan untuk mengetahui pengaruh ataupun juga antara dua variabel atau lebih.Penelitian ini dapat di bangun suatu teori yang dapat berfungsi untuk menjelaskan, meramal dan mengontrol suatu gejala.pemelitian ini termasuk pendekatan kuantitatif karena banyak menggunakan angka-angka mulai dari pengumpulan data, penafsiran data serta penampilan dari hasil pengolahan data tersebut. Sedangkan metode verifikatif adalah metode yang bertujuan untuk mengetaahui hubungan kausalitas antar variabel melalui suatu penguji hipotesis melalui suatu perhitungan statistik sehingga didapat hasil pembuktian yang menunjukan hipotesis diterima atau ditolak.

Analisis ini akan dimulai dengan mengamati perkembangan seluruh variabel yang akan diteliti pada peusahaan Food and beverages yaitu Return on Equity, Price Earning Ratio, Debt to Equity ratio dan Return Saham. Informasi mengenai seluruh variabel diperoleh dari PT. Bursa Efek Indonesia. Return Saham yang menjadi variabel terikat (Dependent Variabel) ini adalah Return Saham pada periode 2012-2014. Data dapat dilihat dalam Tabel 1. Dari tabel 1 nilai Return on Equity rata-rata selama periode 2012-2014 mengalami fluktuasi. Pada tahun 2012 ratarata ROE perusahaan adalah 27.46 kemudian 2013 menurun menjadi 25.45 Pada tahun 2014 terjadi penurunan ratarata ROE perusahaan adalah 24.80. dari data di atas juga diketahui bahwa rata-rata paling tinggi untuk ROE diporoleh oleh PT. Multi Bintang Indonesia Tbk. Dengan tingkatan rata-rata ROE selama tiga tahun adalah 133.19 Sementara tingkat rata-rata paling rendah untuk ROE diperoleh oleh PT. Prasidha Aneka Niaga Tbk. Dengan tingkatan rata-rata ROE selama tiga tahun adalah 3.46. berdasarkan tabel 1 bisa dilihat terjadi fluktuasi nilai ROE dari tahun ke tahun untuk setiap sampel perusahaan food and beverages yang menjadi sampel penelitian. 
Tabel 1Data "return on equity" pada perusahaan food and beverages yang ada di BEI. Tahun 2012-2014.

\begin{tabular}{llcccc}
\hline No. & \multicolumn{1}{c}{ Nama Perusahaan } & 2012 & 2013 & 2014 & Rata-Rata \\
\hline 1. & Wilmar cahaya indonesia & 12.59 & 12.32 & 7.63 & 10.84 \\
2. & Tiga pilar sejahtera food & 12.47 & 14.71 & 10.52 & 10.80 \\
3. & Delta djakarta & 35.68 & 39.98 & 37.68 & 37.78 \\
4. & Indofood CBP sukses makmur & 19.04 & 16.85 & 16.83 & 17.57 \\
5. & Multi bintang indonesia & 137.46 & 118.60 & 143.53 & 133.19 \\
6. & Mayora indonesia & 24.27 & 26.87 & 9.99 & 20.37 \\
7. & Ultra jaya milk industry & 21.08 & 16.13 & 5.96 & 14.39 \\
8. & Nipon indosari corporindo & 22.37 & 20.07 & 19.64 & 20.69 \\
9. & Indofood suskes makmur & 14.00 & 8.90 & 12.48 & 11.79 \\
10. & Sekar laut & 6.15 & 8.19 & 10.75 & 8.36 \\
11. & Sekar Bumi & 12.87 & 16.49 & 15.10 & 14.82 \\
12. & Prasidha aneka niaga & 11.57 & 6.26 & -7.44 & 3.46 \\
\hline \multicolumn{5}{c}{ Rata-Rata Pertahun } \\
\hline \multicolumn{5}{c}{ Sumber : IDX Monthly Statistic } \\
\hline
\end{tabular}

Sumber : IDX Monthly Statistic

Tabel 2. Data "price earning ratio" pada perusahaan food and beverages yang ada di BEI tahun 2012-2014.

\begin{tabular}{|c|c|c|c|c|c|}
\hline No. & Nama Perusahaan & 2012 & 2013 & 2014 & Rata-Rata \\
\hline 1. & Wilmar cahaya indonesia & 6.63 & 5.30 & 22.60 & 11.51 \\
\hline 2. & Tiga pilar sejahtera food & 12.46 & 13.48 & 20.48 & 15.47 \\
\hline 3. & Delta djakarta & 19.13 & 23.01 & 24.72 & 22.28 \\
\hline 4. & Indofood CBP sukses makmur & 19.88 & 26.73 & 27.67 & 24.76 \\
\hline 5. & Multi bintang indonesia & 34.39 & 21.59 & 37.72 & 31.23 \\
\hline 6. & Mayora indonesia & 20.64 & 22.32 & 56.17 & 33.04 \\
\hline 7. & Ultra jaya milk industry & 10.87 & 39.96 & 39.09 & 29.97 \\
\hline 8. & Nipon indosari corporindo & 46.83 & 32.67 & 39.93 & 39.81 \\
\hline 9. & Indofood suskes makmur & 10.54 & 23.14 & 14.67 & 16.11 \\
\hline 10. & Sekar laut & 15.61 & 10.65 & 10.29 & 12.18 \\
\hline 11. & Sekar Bumi & 18.43 & 17.74 & 30.54 & 22.23 \\
\hline 12. & Prasidha aneka niaga & 11.52 & 27.37 & -10.77 & 16.55 \\
\hline & Rata-Rata & 18.91 & 22.00 & 27.89 & 22.93 \\
\hline
\end{tabular}

Dari tabel 2 di bawah nilai Price Earning Ratio rata-rata selama periode 2012-2014 mengalami fluktuasi ke naikan pada tahun 2012 rata-rata PER perusahaan adalah 18.91 kemudian 2013 naik menjadi 22.00 Pada tahun 2014 terjadi kenaikan rata-rata PER perusahaan adalah 27.89. dari data di atas juga diketahui bahwa rata-rata paling tinggi untuk PER diporoleh oleh PT. Nipon Indosari Corporindo Tbk. Dengan tingkatan rata-rata PER selama tiga tahun adalah 39.81 Sementara tingkat rata-rata paling rendah untuk PER diperoleh oleh PT. Wilmar Cahaya Indonesia Tbk. Dengan tingkatan rata-rata PER selama tiga tahun adalah 11.51. berdasarkan tabel 2 bisa dilihat terjadi fluktuasi cenderung naik nilai PER dari tahun ke tahun untuk setiap sampel perusahaan food and beverages yang menjadi sampel penelitian. 
Tabel 4.3 Data "debt to equity ratio" pada perusahaan food and beverages yang ada di BEI tahun 2012-2014.

\begin{tabular}{llcccc}
\hline No. & \multicolumn{1}{c}{ Nama Perusahaan } & 2012 & 2013 & 2014 & Rata-Rata \\
\hline 1. & Wilmar cahaya indonesia & 1.22 & 1.02 & 1.39 & 1.21 \\
2. & Tiga pilar sejahtera food & 0.90 & 1.13 & 1.05 & 1.02 \\
3. & Delta djakarta & 28.64 & 31.20 & 29.04 & 29.62 \\
4. & Indofood CBP sukses makmur & 0.48 & 0.60 & 0.66 & 0.58 \\
5. & Multi bintang indonesia & 2.49 & 0.80 & 3.03 & 2.10 \\
6. & Mayora indonesia & 1.71 & 1.47 & 1.51 & 1.56 \\
7. & Ultra jaya milk industry & 0.44 & 0.40 & 0.39 & 0.41 \\
8. & Nipon indosari corporindo & 0.81 & 1.32 & 1.23 & 1.12 \\
9. & Indofood suskes makmur & 0.74 & 1.04 & 1.08 & 0.95 \\
10. & Sekar laut & 0.93 & 1.16 & 1.16 & 1.08 \\
11. & Sekar Bumi & 1.16 & 1.12 & 1.08 & 1.12 \\
12. & Prasidha aneka niaga & 1.04 & 0.67 & 0.64 & 0.78 \\
\hline & Rata-Rata & 3.38 & 3.49 & 3.52 & 3.46 \\
& & & & \\
\hline
\end{tabular}

Dari tabel 3 di atas nilai Debt to Equity Ratio rata-rata selama periode 2012-2014 mengalami fluktuasi ke naikan pada tahun 2012 rata-rata DER perusahaan adalah 3.83 kemudian 2013 naik menjadi 3.49 Pada tahun 2014 terjadi kenaikan rata-rata DER perusahaan adalah 3.52. dari data di atas juga diketahui bahwa rata-rata paling tinggi untuk DER diporoleh oleh PT. Delta Djakarta Tbk. Dengan tingkatan rata-rata DER selama tiga tahun adalah 29.62 Sementara tingkat rata-rata paling rendah untuk DER diperoleh oleh PT. Ultra Jaya Milk Industry Tbk. Dengan tingkatan rata-rata DER selama tiga tahun adalah 0.41 . berdasarkan tabel 4.3 bisa dilihat terjadi fluktuasi cenderung naik nilai PER dari tahun ke tahun untuk setiap sampel perusahaan food and beverages yang menjadi sampel penelitian.

Tabel 4 Hasil Return Saham Perusahaan Food and Beverages yang terdaftar di bursa efek indonesia tahun 2012-

\begin{tabular}{llcccc}
\multicolumn{7}{c}{2014.} \\
\hline NO. & Kode Perusahaan & 2012 & 2013 & 2014 & Rata-Rata \\
\hline 1. & CEKA & 0.36 & -0.11 & 0.29 & 0.18 \\
2. & AISA & 1.18 & 0.32 & 0.47 & 0.66 \\
3. & DLTA & 1.29 & 0.49 & 0.03 & 0.60 \\
4. & ICBP & 0.50 & 0.31 & 0.28 & 0.36 \\
5. & MLBI & 1.06 & -0.98 & -0.01 & 0.02 \\
6. & MYOR & 0.40 & 0.30 & 0.19 & 0.30 \\
7. & ULTJ & 0.23 & 2.38 & -0.17 & 0.81 \\
8. & ROTI & 1.08 & 0.85 & 0.36 & 0.76 \\
9. & INDF & 0.27 & 0.13 & 0.02 & 0.14 \\
10. & SKLT & 0.29 & 0.00 & 0.67 & 0.32 \\
11. & STTP & 0.34 & 0.29 & 0.46 & 0.36 \\
12. & PSDN & -0.51 & -0.36 & -0.04 & 0.30 \\
\hline & Rata-Rata & 0.62 & 0.54 & 0.25 & 0.40 \\
\hline
\end{tabular}

Sumber : IDX Monthly Statistic

Dari tabel 4 di atas nilai Return Saham rata-rata selama periode 2012-2014 mengalami fluktuasi penurunan pada tahun 2012 rata-rata Return Saham perusahaan adalah 0.62 kemudian 2013 menurun menjadi 0.54 Pada tahun 2014 terjadi penurunan rata-rata Return Saham perusahaan adalah 0.25. dari data di atas juga diketahui bahwa ratarata paling tinggi untuk Return Saham diporoleh oleh PT. Ultra Jaya Milk Industry Tbk. Dengan tingkatan rata-rata Return Saham selama tiga tahun adalah 0.81 Sementara tingkat rata-rata paling rendah untuk Return Saham diperoleh oleh PT. Multi Bintang Indonesia Tbk. Dengan tingkatan rata-rata Return Saham selama tiga tahun adalah 
0.02 berdasarkan tabel 4.5 bisa dilihat terjadi fluktuasi cenderung menurun nilai Return Saham dari tahun ke tahun untuk setiap sampel

Analisis deskriptif menunjukkan data terendah (minimum), data tertinggi (maximum), nilai rata-rata (mean), dan tingkat penyebaran data (standard deviasi). Hasil dari penelitian statistik deskriptif adalah sebagai berikut.

\subsection{Analisis Data dan Pengujian Hipotesis \\ 3.1.1. Analisis Statistik Deskriptif}

Pada tabel diatas, menunjukkan bahwa jumlah data yang digunakan dalam penelitian ini adalah sebanyak 36 sampel dengan periode 3 tahun yaitu pada tahun 2012 - 2014 dengan 12 perusahaan. Variabel Return on Equity menunjukkan nilai mean sebesar 25.4886 yang berarti bahwa Return on Equity berpengaruh terhadap Return saham dengan presentase rata - rata sebesar $25.4886 \%$. Nilai minimum variabel Return on Equity yaitu sebesar -7.44 dan nilai maximum yaitu sebesar 143.53.

Variabel Price Earning Ratio menunjukkan nilai mean sebesar 22.3333 yang berarti bahwa Price Earning Ratio berpengaruh terhadap Return saham dengan presentase rata - rata sebesar $22.3333 \%$. Nilai minimum variabel Price Earning Ratio yaitu sebesar -10.77 dan nilai maximum yaitu sebesar 56.17 .

Variabel Debt to Equity Ratio menunjukkan nilai mean sebesar 3.4653 yang berarti bahwa Debt to Equity Ratio berpengaruh terhadap Return saham dengan presentase rata - rata sebesar $3.4653 \%$. Nilai minimum variabel Debt to Equity Ratio yaitu sebesar -39 dan nilai maximum yaitu sebesar 31.20.

Variabel return saham menunjukkan nilai mean sebesar 0.3517. Nilai minimum variabel Price Earning Ratio yaitu sebesar -0.98dan nilai maximum yaitu sebesar 2.38.

\subsection{Hasil Uji Asumsi Klasik}

\subsubsection{Normalitas}

Uji normalitas digunakan untuk mengetahui apakah variabel independen dan variabel dependen mempunyai distribusi normal ataukah tidak. Dalam penelitian ini digunakan pengujian data uji normalitas dengan KolmogrovSmirnov. Hasil pengujian adalah sebagai berikut.

Tabel 5. Hasil Uji Normalitas

\begin{tabular}{lllll}
\hline & $\begin{array}{l}\text { Unstandardized } \\
\text { Residual }\end{array}$ & Kriteria & Keputusan & Kesimpulan \\
\hline $\begin{array}{l}\text { Kolmogrov- } \\
\text { Smirnov Z }\end{array}$ & 0.946 & & & \\
$\begin{array}{l}\text { Asymp. Sig. } \\
\text { (2-Tailed) }\end{array}$ & 0.332 & Nilai sig $>0.05$ & $0.332>0.05$ & Normal \\
\hline
\end{tabular}

Berdasarkan hasil uji normalitas Kolmogrov-Smirnov diatas, besarnya taraf probabilitas uji Asymp.Sig.(2tailed) adalah sebesar 0,333( $\rho=0,333)$. $\rho=0,332>\alpha=0,05$ yang berarti bahwa hasil uji normalitas lebih besar dari taraf probabilitas uji Asymp, maka H0 diterima dan $\mathrm{H} 1$ ditolak yang memberikan kesimpulan bahwa data berdistribusi normal.

\subsubsection{Uji Multikolinearitas}

Uji ini bertujuan untuk mengetahui adanya hubungan yang sempurna antara variabel independen dalan regresi. Jika nilai VIF > 10, maka variabel mempunyai hubungan multikolnearitas dengan variabel independen lainnya.

Tabel 6. Hasil Uji Multikolinearitas

\begin{tabular}{llll}
\hline Variabel & VIF & Kriteria & Kesimpulan \\
\hline Return on Equity & 1.231 & VIF $<10$ & Tidak ada multikolinearitas \\
Price Earning Ratio & 1.323 & VIF $<10$ & Tidak ada multikolinearitas \\
Debt to Equity Ratio & 1.004 & VIF $<10$ & Tidak ada multikolinearitas \\
\hline
\end{tabular}

Dari tabel diatas, menunjukkan nilai VIF dari ketiga variabel independen lebih kecil dari angka 10 yang menyimpulkan bahwa dari ketiga variabel independen tersebut tidak terdapat adanya multikolinearitas. 


\subsubsection{Uji heteroskedastisitas}

Uji ini bertujuan untuk mendekteksi penyebaran variabel dan ketidaksamaan antar variabel.

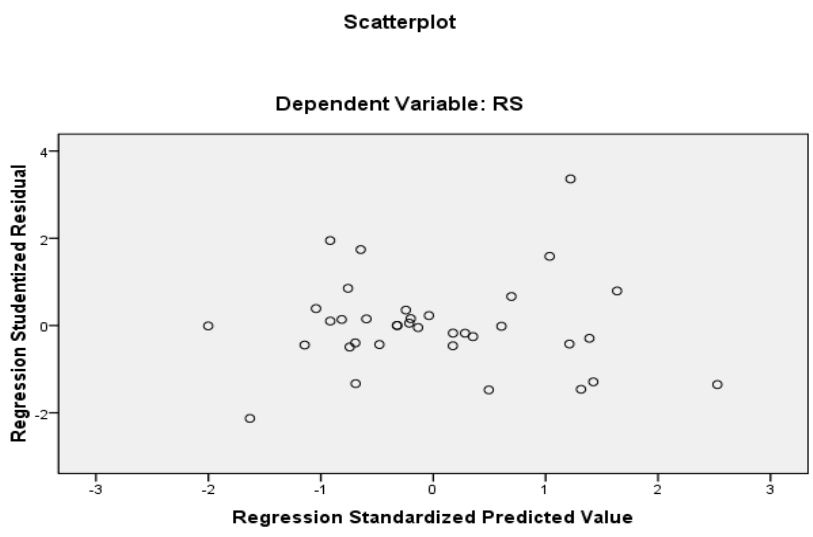

Gambar 1. Hasil Uji Heteroskedastisitas

Pada gambar diatas menunjukkan bahwa pada scatterplot titik-titik menyebar diatas angka 0 pada sumbu $\mathrm{Y}$ dan tidak membentuk pola yang jelas yang berarti bahwa tidak adanya heteroskedastisitas.

\subsubsection{Uji Autokorelasi}

Uji Autokorelasi pada model regresi artinya ada korelasi antar anggota sampel yang diurutkan berdasarkan waktu saling berkorelasi. Untuk mengetahui adanya autokorelasi dalam suatu model regresi dilakukan melalui pengujian terhadap nilai uji Durbin Watson ( Uji DW) :

Kurang dari $1,10=$ ada autokorelasi

$1,10 \mathrm{~s} / \mathrm{d} 1,54=$ tanpa kesimpulan

$1,55 \mathrm{~s} / \mathrm{d} 2,46=$ tidak ada autokorelasi

$2,46 \mathrm{~s} / \mathrm{d} 2,90 \quad=$ tanpa kesimpulan

Lebih dari $2,91=$ ada autokorelasi

Tabel 7. Uji Autokorelasi

Model Summary ${ }^{\mathrm{b}}$

\begin{tabular}{cccccr}
\hline & & & Adjusted R & Std. Error of the & Durbin-Watson \\
Model & $\mathrm{R}$ & R Square & Square & Estimate & \\
1 & $.596^{\mathrm{a}}$ & .355 & .301 & 1.09251 & 1.270 \\
\hline
\end{tabular}

a. Predictors: (Constant), DER, PER, ROE

b. Dependent Variable: RS

Berdasarkan hasil uji pada tabel 7 diatas maka diperoleh nilai Durbin Watson sebesar 1.270 berada diantara 1,10 s/d 1,54 maka di simpulkan bahwa DW test berada pada daerah bebas autokorelasi tanpa kesimpulan.

\subsubsection{Uji t ( Parsial)}

Uji t digunakan untuk mengetahui pengaruh masing-masing variabel independen terhadap variabel dependennya. Berikut adalah hasil dari uji t :

\begin{tabular}{cccc} 
& Tabel 8. Hasil Uji t \\
Variabel & Uji t & \\
& t hitung & Sig. & Keputusan \\
\hline Return on Equity $\left(\mathrm{X}_{1}\right)$ & 729 & 0.041 & $\mathrm{H}_{1}$ diterima \\
Price Earning Ratio $\left(\mathrm{X}_{2}\right)$ & 1.178 & 0.026 & $\mathrm{H}_{2}$ diterima \\
Debt to Equity Ratio $\left(\mathrm{X}_{3}\right)$ & 3.254 & 0.000 & $\mathrm{H}_{3}$ diterima \\
\hline
\end{tabular}

1. Hasil uji t variabel current ratio (X1) terhadap return on asset (Y). 
a. $\quad \mathrm{H} 0: \beta 1=0$, artinya variabel Return on Equity tidak mempunyai pengaruh yang signifikan terhadap return saham.

b. $\quad H 1: \beta 1 \neq 0$, artinya variabel Return on Equity mempunyai pengaruh yang signifikan terhadap return saham.

Berdasarkan hasil analisis regresi, nilai koefisien regresi variabel Return on Equity sebesar 0.098 dan nilai t hitung sebesar 0.729 dengan nilai signifikasi sebesar 0.041. Nilai signifikasi 0.041 lebih besar dari $\alpha$ sebesar 5\% (0.05), ), maka $\mathrm{H} 0$ ditolak dan $\mathrm{H} 1$ diterima yang artinya variabel retun on equity berpengaruh secara parsial terhadap return saham. Arah pengaruh variabel Retun on Equity terhadap return saham adalah positif yang artinya bahwa semakin tinggi nilai Return on Equity maka nilai return saham akan semakin tinggi, semakin rendah nilai Return on Equity maka nilai return saham juga akan semakin rendah.

2. Hasil uji t variabel Price earning Ratio (X2) terhadap return saham (Y).

a. $\mathrm{H} 0: \beta 2=0$, artinya variabel Price earning Ratio tidak mempunyai pengaruh yang signifikan terhadap return saham.

b. H0 : $\beta 2 \neq 0$, artinya variabel Price earning Ratio mempunyai pengaruh yang signifikan terhadap return saham.

Berdasarkan hasil analisis regresi, nilai koefisien regresi variabel Price earning Ratio sebesar 0.158 dan nilai t hitung sebesar 1.178 dengan nilai signifikasi sebesar 0.026 . Nilai signifikasi 0.026 lebih besar dari $\alpha$ sebesar 5\% (0.05), ), maka H0 ditolak dan H1 diterima yang artinya variabel Price earning Ratio berpengaruh secara parsial terhadap return saham. Arah pengaruh variabel Price earning Ratio terhadap return saham adalah positif yang artinya bahwa semakin tinggi nilai Price earning Ratio maka nilai return saham akan semakin tinggi, semakin rendah nilai Price earning Ratio maka nilai return saham juga akan semakin rendah.

3. Hasil uji t variabel debt to equity ratio (X3) terhadap return saham (Y).

a. $\mathrm{H} 0: \beta 3=0$, artinya variabel debt to equity ratio tidak mempunyai pengaruh yang signifikan terhadap return saham.

b. $\mathrm{H} 0: \beta 3 \neq 0$, artinya variabel debt to equity ratio mempunyai pengaruh yang signifikan terhadap return saham.

Berdasarkan hasil analisis regresi, nilai koefisien regresi variabel debt to equity ratio sebesar 0.059 dan nilai t hitung sebesar 3.254 dengan nilai signifikasi sebesar 0.000. Nilai signifikasi 0.000 lebih besar dari $\alpha$ sebesar 5\% (0.05), ), maka $\mathrm{H} 0$ ditolak dan $\mathrm{H} 1$ diterima yang artinya variabel debt to equity ratio berpengaruh secara parsial terhadap return saham. Arah pengaruh variabel debt to equity ratio terhadap return saham adalah positif yang artinya bahwa semakin tinggi nilai debt to equity ratio maka nilai return saham akan semakin tinggi, semakin rendah nilai debt to equity ratio maka nilai return saham juga akan semakin rendah.

\subsubsection{UJI F (simultan)}

Uji $\mathrm{F}$ digunakan untuk mengetahui pengaruh semua variabel independen terhadap variabel dependennya dalam model regresi. Berikut adalah hasil dari uji F :

Tabel 9. Hasil Uji F (Simultan)

\begin{tabular}{llrrrrr}
\multicolumn{7}{c}{ Anova $^{\mathrm{b}}$} \\
\hline Model & & Sum of Squares & $\mathrm{df}$ & Mean Square & F & \multicolumn{1}{c}{ Sig. } \\
\hline 1 & Regression & 1.311 & 3 & .437 & 1.389 & $.024^{\mathrm{a}}$ \\
& Residual & 10.069 & 32 & .315 & & \\
& Total & 11.380 & 35 & & & \\
\hline
\end{tabular}

a. Predictors: (Constant), DER, PER, ROE

1. Kriteria pengujian :

$\mathrm{H} 0=\beta 1=\beta 2=\beta 3=0$, artinya variabel bebas X1 X2 X3 secara bersama-sama tidak mempunyai pengaruh yang signifikan terhadap return saham.

$\mathrm{H} 0=\beta 1 \neq \beta 2 \neq \beta 3 \neq 0$, artinya variabel bebas X1 X2 X3 secara bersama-sama mempunyai pengaruh yang signifikan terhadap return saham.

2. Penerimaan atau penolakan hipotesis dengan tingkat signifikasi sebesar $5 \%$.

a. Jika nilai sig.uji $\mathrm{F}<\alpha$, maka $\mathrm{H} 0$ ditolak.

b. Jika nilai sig.uji $\mathrm{F}>\alpha$, maka H0 diterima. 
c. Hasil sig. Uji F adalah sebesar 0.024

Besarnya nilai signifikasi uji $\mathrm{F}$ ketiga variabel bebas yaitu sebesar $0.024<5 \%$, maka H0 ditolak yang menunjukkan bahwa secara simultan atau bersama-sama variabel bebas return on equity, price earning ratio dan debt to equity ratio mempunyai pengaruh simultan yang signifikan terhadap variabel terikat yaitu return saham.

\subsubsection{Koefisien determinasi}

Tabel 10. Nilai koefisien determinasi

\begin{tabular}{cccc}
\hline $\mathrm{R}$ & $\mathrm{R}$ Square & Adjusted R Square & $\begin{array}{c}\text { Std. Error of the } \\
\text { Estimate }\end{array}$ \\
\hline 0.596 & 0.355 & 0.301 & 1.09251 \\
\hline
\end{tabular}

Dari model regresi linier berganda yang telah dihitung, nilai koefisien determinasi yang didapatkan adalah sebesar 35.5\%. Yang artinya bahwa besarnya pengaruh variabel bebas yaitu return on equity, price earning ratio dan debt to equity ratio terhadap variabel terikat return saham yaitu sebesar $35.5 \%$, sedangkan $64.5 \%$ nya dipengaruhi oleh variabel lain diluar penelitian.

\section{Pembahasan dan Hasil Penelitian}

Hasil dari analisis diatas menunjukkan bahwa variabel bebas yang terdiri dari return on equity, price earning ratio dan debt to equity ratio secara simultan atau bersama-sama mempunyai pengaruh yang tidak signifikan terhadap variabel terikat return saham, karena mempunyai nilai probabilitas lebih dari 0.05. Dapat dilihat dari nilai koefisien determinasi bahwa sebesar 35.5\% variabel bebas mempengaruhi variabel terikat dan sebesar $64.5 \%$ dipengaruhi oleh variabel lain diluar penelitian.

\subsection{Pengaruh return on equity terhadap Return saham}

Berdasarkan hasil uji t dinyatakan bahwa variabel return on equity berpengaruh secara parsial terhadap return saham karena nilai sig. $t$ hitung lebih kecil dari $\alpha$ yaitu $5 \%$. Hal ini membuktikan bahwa hipotesis pertama terbukti yang menyatakan bahwa terdapat tidak mempunyai pengaruh signifikan return on equity terhadap Return saham. Nilai regresi return on equity sebesar 0.041 yang berarti return on equity memiliki pengaruh signifikan terhadap return saham.

Hasil ini mengindikasikan bahwa besarnya perusahaan berpengaruh signifikan terhadap return saham. Hasil ini bertentangan dengan teori bahwa return on equity merupakan tolak ukur profitabilitas dimana para pemegang saham pada umumnya ingin mengetahui tingkat profibilitas modal saham dan keuntungan yang telah mereka tanam kembali dalam bentuk laba yang ditanam. Apabila saham perusahaan diperdagangkan dibursa saham, tinggi rendahnya return on equity akan mempengaruhi tingkat permintaan saham tersebut dibursa dan harga jualnya. Hal ini menunjukkan faktor lainnya yang mempengaruhi return saham perusahaan food and beverages selama periode penelitian 2012 - 2014. Hasil ini sejalan dengan penelitian yang dilakukan oleh khodijah (2010) dan susilowati (2011) yang menyatakan ROE memiliki pengaruh signifikan terhadap return saham.

\subsection{Pengaruh price earning ratio terhadap Return saham}

Berdasarkan hasil uji t dinyatakan bahwa variabel price earning ratio berpengaruh secara parsial terhadap return saham karena nilai sig. $t$ hitung lebih kecil dari $\alpha$ yaitu 5\%. Hal ini membuktikan bahwa hipotesis pertama terbukti yang menyatakan bahwa terdapat tidak mempunyai pengaruh signifikan return on equity terhadap Return saham. Nilai regresi price earning ratio sebesar 0.026 yang berarti price earning ratio memiliki pengaruh signifikan terhadap return saham.

Variabel Price earning Ratio berpengaruh secara parsial terhadap return saham. Arah pengaruh variabel Price earning Ratio terhadap return saham adalah positif yang artinya bahwa semakin tinggi nilai Price earning Ratio maka nilai return saham akan semakin tinggi, semakin rendah nilai Price earning Ratio maka nilai return saham juga akan semakin rendah. Apabila nilai PER rendah dari suatu saham menunjukan harga saham tersebut lebih murah dibandingkan harga saham sejenisnya, sehingga pada suatu saat ketika harga saham mulai mengalami koreksi kenaikan,diharapkan investor yang membeli harga saham dengan PER yang rendah akan mendapatkan keuntungan yang tinggi. Jadi price earning ratio berpengaruh signifikan terhadap return saham. 


\subsection{Pengaruh debt to equity ratio terhadap Return saham}

Berdasarkan hasil uji t dinyatakan bahwa variabel debt to equity ratio berpengaruh secara parsial terhadap return saham karena nilai sig. t hitung lebih kecil dari $\alpha$ yaitu 5\%. Hal ini membuktikan bahwa hipotesis pertama terbukti yang menyatakan bahwa terdapat tidak mempunyai pengaruh signifikan debt to equity ratio terhadap Return saham. Nilai regresi return on equity sebesar 0.000 yang berarti debt to equity ratio memiliki pengaruh signifikan terhadap return saham.

Hasil ini menunjukkan bahwa tidak dipengaruhi secara nyata oleh perubahan porsi sumber dana dari pinjaman (DER) terhadap return saham perusahaan food and beverages selama periode penelitian 2012 - 2014 karena return saham juga dipengaruhi lagi oleh faktor lainnya selain DER. Meskipun DER mempunyai pengaruh yang positif, bukan berarti bahwa perusahaan dapat menentukan proporsi hutang dengan setinggi - tingginya, karena akan menimbulkan resiko yang besar. Para pemodal akan menetapkan tingkat keuntungan yang lebih besar lagi terhadap setiap rupiah yang ditanam perusahaan tersebut, sehingga nilai perusahaan cenderung turun. Hasil ini sejalan dengan penelitian yang dilakukan oleh subiyantoro (2003) dan trisnaeni (2007) yang menyatakan bahwa DER memiliki pengaruh yang signifikan terhadap return saham.

\subsection{Pengaruh Return on Equity, Price Earning Ratio dan Debt to Equity Ratio terhadap Return Saham}

Dari hasil pengujian simultan terhadap variabel ROE, PER dan DER terhadap Return saham perusahaan food and beverages periode 2012-2014 di peroleh hasil besarnya nilai signifikasi uji F ketiga variabel bebas yaitu sebesar $0.024<5 \%$, maka H0 ditolak yang menunjukkan bahwa secara simultan atau bersama-sama variabel bebas return on equity, price earning ratio dan debt to equity ratio mempunyai pengaruh simultan yang signifikan terhadap variabel terikat yaitu return saham.

\section{Penutup}

Berdasarkan penelitian yang telah dilakukan dan dijelaskan di bab - bab sebelumnya, maka dapat diambil kesimpulan sebagai berikut :

1. Kondisi keluarga keuangan yang diukur dengan ROE, PER dan DER pada perusahaan food and beverages selama periode 2012 - 2014. Menunjukkan kondisi yang baik secara umum. Perusahaan-perusahaan tersebut menunjukan adanya peningkatan ROE selama periode penelitian secara umum pada sebagian besar sampel bisa di pertahankan pada nilai positif tidak terlalu banya perusahaan yang menurun nilai ROE nya tiap tahun. Untuk tingkatan PER dan DER sendiri perusahaan food and beverages mampu menjaga tingkat PER dan DER pada angka yang rendah. Menunjukan bahwa kinerja penelitian kinerja keuangan perusahaan food and beverages selama periode penelitian mampu menjaga kemampuannya dalam menghasilkan laba juga untuk memenuhi kewajiban-kewajibannya.

2. Kondisi retun saham pada perusahaan food and beverages pun berada dikondisi yang baik. Sebagaian besar perusahaan sampel mampu menjaga tingkatan return saham pada angka positif, kecuali PT. Multi Bintang Indonesia memiliki nilai saham yang menurun pada tahun 2013 dan 2014. Hal ini menunjukan bahwa perusahaan mampu menjaga kondisi harga sahamnya sehingga bisa menghasilkan return saham yang positif, meskipun terdapat fluktuasi selama periode penelitian yang dipengaruhi oleh berbagai kondisi.

3. Dari hasil pengujian yang telah dilakukan terhadap keseluruhan kinerja keuangan yang diukur dengan ROE, PER dan DER terhadap return saham perusahaan food and beverages periode 2012-2014, diperoleh H0 diterima, maka analisis statistik memberikan hasil bahwa kinerja keuangan yang diukur dengan ROE, PER dan DER memiliki pengaruh signifikan terhadap return saham pada perusahaan food and beverages selama periode 20122014. Sehingga dapat di tarik kesimpulan bahwa ROE, PER dan DER berpengaruh simultan terhadap return saham.

4. Pengujian secara parsial pada pengaruh kinerja keuangan yang di ukur dengan ROE, PER dan DER terhadap return saham menghasilkan sebagai berikut :

a. Dari hasil penelitian menguji pengaruh kinerja keuangan (ROE) terhadap return saham pada perusahaan food and beverages di peroleh HO diterima, yang berarti terdapat pengaruh signifikan kinerja keuangan (ROE) terhadap return saham.

b. Dari hasil penelitian menguji pengaruh kinerja keuangan (PER) terhadap return saham pada perusahaan food and beverages di peroleh $\mathrm{H} 0$ diterima, yang berarti terdapat pengaruh signifikan kinerja keuangan (PER) terhadap return saham. 
c. Dari hasil penelitian menguji pengaruh kinerja keuangan (DER) terhadap return saham pada perusahaan food and beverages di peroleh HO diterima, yang berarti terdapat pengaruh signifikan kinerja keuangan (DER) terhadap return saham.

d. Variabel independen ROE, PER dan DER masih berpengaruh positif terhadap return saham dan juga diketahui bahwa nilai signifikan variabel ROE, PER dan DER masih dibawah nilai signifikan marjinal 10\%, sehingga ROE, PER dan DER mesih sangat pontesial digunakan sebagai variabel yang mempengaruhi return saham.

\section{Daftar Pustaka}

Akdon, dan Ridwan. 2006. Aplikasi stastistik dan metode penelitian untuk administrasi dan manajemen. Bandung: Dewa Ruci.

Dharmastuti Fara. 2004. Analisis pengaruh earning per share, price earning ratio, return on invesment, debt to equity, dan profit margin dalam penetapan harga saham perdana. (jurnal fakultas ekonomi universitas atmajaya, no.2, september, Hal 14-28). Jakarta.

Hair, et. Al 1992. Multivariate data analysis with readings. USA: Macmillan.

Koetin, E. A. 1992. Analisis pasar modal. Jakarta: pustaka sinar harapan. 1992.

Munawir, 2004.analisis rasio yang dapat mengukur tingkat profitabilitas,liquiditas.

Trisnaeni, Dyah Kumala.(2007). Pengaruh kinerja keuangan terhadap return saham perusahaan manufaktur yang terdaftar di BEI (skripsi). Jogyakarta: fakultas Ekonomi Islam Indonesia.

Raharjo, Susilo. 2005. Analisis pengaruh kinerja keuangan terhadap return saham pada perusahaan LQ45 di bursa efek jakarta (skripsi). Yogyakarta: fakultas ekonomi universitas islam indonesia.

Resmi, siti. 2002." Keterkaitan kinerja keuangan perusahaan dengan harga saham ( studi 25 emitnen 4 rasio keuangan di BEI". yogyakarta. Vol 6 september 2002.

Sucipto. 2003. Penelitian kinerja keuangan. http://digilib.usu.ac.id/download/fe/akuntasi-sucipto.pdf. (accessed 23 m3i 2012)

Soerinawati, Wiwik, 2003. Analisis pengaruh kinerja keuangan perusahaan terhadap return saham pada sektor perdagangan besar dan eceran dibursa efek jakarta(Tesis). Semarang: program pascasarjana universitas diponogoro.

Suharli, M. 2004. "studi emperis terhadapfaktor penentu kebijakan jumlah deviden" tesis magister akuntasi

Sugiono. 2003. Metode penelitian kuantitatif, kualitatif, R\&D. Bandung: alfabeta.

Sulistyo, Basuki. 2006. Metode penelitian. Jakarta : wedatama widya sastra dan fakultas ilmu pengetahuan budaya universitas indonesia.

Susilowati, Yeye dan Tri Turyanto,(2011). Reaksi rasio profitabilitas dan rasio solvabilitas terhadap return saham perusahaan. ( jurnal dinamika keuangan dan perbankan, Vol.3,No.1, Mei, hal 17-37 ). 